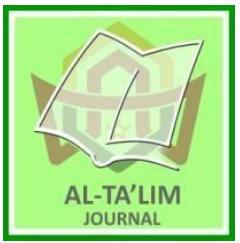

AL-TA'LIM JOURNAL, 28 (3), 2021, (261-272)

(Print ISSN 1410-7546 Online ISSN 2355-7893)

Available online at http://journal.tarbiyahiainib.ac.id/index.php/attalim

\title{
Competency Characteristics of Graduates Viewed from User Satisfaction Using Nonhierarchical Clusters
}

Received: 04 ${ }^{\text {th }}$ December 2020; Revised: 02 ${ }^{\text {nd }}$ April 2021; Accepted: $30^{\text {th }}$ November 2021

Permalink/DOI: http://dx.doi.org/10.15548/it.v28i3.671

\section{Muhammad Ikhsan Ghozali *) \\ Institut Agama Islam Negeri Syaikh \\ Abdurrahman Siddik Bangka Belitung, Indonesia \\ E-mail: madsanli@yahoo.com}

\section{Heri Retnawati}

Universitas Negeri Yogyakarta, Indonesia.

E-mail: heri_retnawati@uny.ac.id

\section{*) Corresponding Author}

\begin{abstract}
This study aims to classify graduates based on the similarity of competency characteristics by referring to the indicators of graduate user satisfaction. The indicators are implementation of Islamic values; integrity, ethics, and morals; expertise based on knowledge (professionalism); foreign language skills; ability to use ICT; communication; teamwork; and self-development. The survey was aimed at graduates of five study programs totaling 211 people. Determination of respondents using the purposive sampling technique. Data was collected through a questionnaire containing statements about the eight indicators. Data analysis uses descriptive and multivariate statistics with the non-hierarchical cluster method or K-Means cluster analysis, assisted with SPSS (Statistical Package for Social Science) software. The results show that based on the similarity of competency characteristics, graduates are grouped into three clusters, namely Cluster 1 with $13.27 \%$ with characteristics of graduates with low competence, Cluster 2 with $32.7 \%$ with characteristics of graduates with high competence, and Cluster 3 with $54.03 \%$ with the characteristics of graduates with moderate competence. Thus, a strategic program that is systematic, comprehensive, and continuous is needed to develop human resources to shape the quality mentality and competence of students and to be competitive with students and by the needs of the workforce or users. For this reason, it is necessary to develop an e-tracer system that is integrated with the campus web and to strengthen synergistic cooperation with stakeholders, including users.
\end{abstract}

Keywords: Non-hierarchical cluster analysis; K-Means cluster analysis; characteristics of graduate competence.

How to Cite: Ghozali, M., \& Retnawati, H. (2021). Competency Characteristics of Graduates Viewed from User Satisfaction Using Nonhierarchical Clusters. Al-Ta lim Journal, 28(3). doi:https://doi.org/10.15548/jt.v28i3.671

\section{INTRODUCTION}

Graduates who have superior competence, both academic and nonacademic under the specified profile, are the expectations of all tertiary institutions (Christensen et al., 2011; Hilliard, 2015). Moreover, in a competitive era like now so that every university continues to improve its quality to be able to compete (Gunarto \&
Septayuda, 2016). The quality of higher education is reflected in the profile of its graduates, especially in terms of its suitability to the needs of the world of work (Jain et al., 2011; Teeroovengadum et al., 2016).

Santyadiputra \& Agustini (2016); Setyaningsih \& Abrori (2013) said that the issue of the quality of tertiary education graduates was inseparable from internal and 
external factors in the implementation system. Internal factors are the role of tertiary institutions, while external factors are parties outside of tertiary institutions, one of which is the user of graduates. In this case, universities as service providers must produce quality graduates who are ready to use by users (Bertaccini et al., 2021; Ciriaci, 2014; Shah et al., 2015). This is related to the theory of supply and demand, where there must be relevance between the availability of highquality college graduates with the needs of users (Imron \& Farda, 2019). Whether or not the quality of graduates depends on the user or customer, both in terms of the suitability of graduate expertise with the needs of the field of work and perceived quality is good or satisfying (Pyrhönen et al., 2020; Summers, 2016). Users will always compare their expectations with the reality they get from college graduates, whether or not they are, good or bad, and satisfied or not. This is in line with the views of Pradela (2015) that customer satisfaction can be measured from the suitability of expectations and their perceptions of the services received.

In connection with this, the survey of graduate user satisfaction as part of tracer study activities is one of the efforts that should always be done by universities (Adeniran, 2011; Xu \& Du, 2019). Tracer study is an empirical study of the track record of college graduates. The aim is to get information about the condition of graduates after completing the education process in higher education (Hazaymeh \& Dela Peña, 2017; Rogan \& Reynolds, 2016). Information obtained from tracer studies varies, including the relationship between universities and the professional world of work and the relevance of the profile of graduates with the needs of the world of work (Heriyadi, 2021; Kalaw, 2019). The results of the tracer study provide feedback related to the evaluation of educational outcomes on the successes and deficiencies in the education and learning process so that they can be taken into consideration in formulating policies for fundamental improvement, refinement, and quality assurance of higher education (Calpa et al., 2021; Kartika et al., 2019; Lucitasari \&
Khannan, 2019; Schomburg, 2014). However, according to Izogo \& Ogba (2015) efforts to measure customer satisfaction are not easy because they depend on the level of aspirations and expectations. Therefore, West et al. (2015) customer satisfaction must be accompanied by monitoring of their needs and desires.

In line with this, the State Islamic Institute of Shaykh Abdurrahman Siddik Bangka Belitung (IAIN SAS Bangka Belitung) as one of the universities that are still in the process of developing, information about the perceptions of graduates related to the suitability of graduates with the needs of the world of work is very much needed. Therefore, the Quality Assurance Institute (LPM) IAIN SAS Bangka Belitung surveyed graduate user satisfaction. In general, the survey aims to find out how far IAIN SAS Bangka Belitung graduates can be absorbed in the world of work. While specifically, the survey aims to find out, (1) what percentage of graduates are employed, (2) the quality of competencies possessed by graduates, and (3) updating the competency of graduates required by graduates in the world of work.

Since its establishment, IAIN SAS Babel has experienced several phases of change in status and form, namely the Tarbiyah College of Sciences and the College of Islamic Religion under the auspices of the Bangka Islamic Higher Education Foundation. Then it was changed into a state and became the Islamic High School of the State of Shaykh Abdurrahman Siddik Bangka Belitung in October 2005. Then, in April 2018 it was transformed from a high school into an institute. At present, IAIN SAS Babel has three faculties and 13 study programs, namely: the Tarbiyah Faculty with the PAI Study Program (Islamic Religious Education), PIAUD (Early Childhood Islamic Education), TBI (English Tadris), PBA (Arabic Language Education), and BKPI (Islamic Education Guidance and Counseling); Faculty of Da'wah and Communication with BKI Study Program (Islamic Guidance and Counseling), KPI (Islamic communication and Broadcasting), PI (Islamic Psychology), and JI (Islamic Journalism), and Faculty of Sharia and 
Islamic Economics with Study Program PS (Islamic Banking), AS (al-Ahwal alSyahsiyah), and AkS (Islamic Accounting).

Because only five study programs already have graduates scattered, the survey was conducted with alumni users from the five study programs (study programs), who graduated between 2015 and 2018. The five study programs referred to were PAI, PIAUD, TBI, BKI, and PS The indicators used in the survey refer to the attachment to BAN-PT Regulation No. 59 of 2018 concerning Guidelines for Preparation of Self Evaluation Reports, Guidelines for Preparation of Higher Education Performance Reports, and Assessment Matrix in Higher Education Accreditation Instruments. Based on the attachment to the regulation, the following eight indicators are established: (1) application of Islamic values; (2) integrity, ethics, and morals; (3) expertise based on knowledge (professionalism); (4) foreign language skills; (5) the ability to use information and communication technology (ICT); (6) Communication; (7) Teamwork; and (8) self-development. The results show that several issues are important to be considered by the IAIN SAS Bangka Belitung related to graduate competencies, especially in terms of mastering foreign languages and the ability to master ICT (Team 2019).

Even so, the survey results are still general and have not combined the level of user satisfaction with graduate competencies and have not classified them based on similar characteristics of graduate competencies. Through a description of the group's characteristics, the ability of graduates can complement existing results. Therefore, this study tries to enrich the results of a survey conducted by LPM IAIN SAS Bangka Belitung by grouping graduates based on these characteristics in common by using one of the clustering methods, namely cluster nonhierarchical analysis or K-Means cluster analysis. The purpose of this grouping, in addition to minimizing the objective function in the process, also minimizes variation in a cluster and maximizes variation between clusters. Johnson \& Wichern (2014) also mentions some of the benefits of this cluster analysis, namely classifying very large survey data into classification groups, reducing large information from a population to specific information, and building hypotheses based on the original data or confirming information from hypotheses that already existed.

The use of this method is due to the nonhierarchical cluster analysis method or KMeans cluster analysis is one of the most frequently used methods (Pravitasari, 2009). This method identifies objects with certain characteristics in common and uses these characteristics as centroids or mean scores for specific clusters (Aranda \& Natasya, 2016; Ediyanto \& Satyahadewi, 2013; Nasari \& Darma, 2013). Even this method can be a solution to classify the characteristics of objects because it has a high accuracy of the size of the object (Aranda \& Natasya 2016). This, according to Ediyanto, et al. (2013) because in the K-Means cluster analysis method, the set of variables is determined by the researcher, whereas other multivariate analyzes estimate the set of variables empirically. Even so, the determination of this set of variables must be done carefully because, according to experts, the stage of determining this set is critical in cluster analysis.

In general, surveys of user satisfaction in college graduates and research using clustering methods have been carried out. Some graduate user satisfaction surveys, for example: (1) Hafiz (2020) about tracer study of alumni of Islamic Education Study Program for Early Childhood STAIN Gajah Putih Takengon; (2) Dorji \& Singh (2020) about tracer study: an analysis of 2018 graduates of Gedu College of Business Studies, Bhutan; (3) Shobirin et al. (2019) concerning the absorption and satisfaction of PGMI Unwahas alumni graduates in 2015, 2016 and 2017; (4) Rantesalu (2019) regarding user satisfaction of graduates of the Christian Religious Education Study Program in Kupang State Christian High School in 2019; (5) Odame et al. (2021) concerning tracer study related to university preparation and work capabilities of visually impaired graduates in Ghana; (6) Safi'i \& Priyantoro (2019) about tracer study as an effort to 
improve alumni careers in attending university job placement services; (7) Khasanah (2019) about tracer study as an effort to improve higher Islamic education quality and relevance; (8) Jurnal (2019) about evaluating e-tracer studies using the HOT (human-organization technology) fit model; (9) Primasari (2018) concerning the development of an alumni portal information system with tracer study and survey of alumni users of Atma Jaya University Yogyakarta; (10) Soegoto et al. (2018) about e-tracer study implementation of Indonesia Computer University alumni; (11) Arifin \& Muzid (2018) about tracer analysis of studies at XYZ University; (12) Rahim \& Puluhulawa (2018) about tracer studies of graduates of the Guidance and Counseling Study Program, Gorontalo State University.

As for some studies with clustering methods, for example: (1) Hatidja et al. (2018) classifying courses in the Physics Study Program Unsrat based on the learning process; (2) Övgü Çakmak-Otluoğlu (2018) who examined a cluster analysis of protean and boundaryless career orientations: relationships with career competencies; (3) Chen \& Duan (2019) who wrote research on clustering analysis of Internet public opinion; (4) Irmeilyana et al. (2017) grouping students based on their GPA and IP of subject groups and interest groups; (5) Poerwanto \& Fa'rifah (2016) who group students' abilities using KMeans cluster analysis; (6) Aquino et al. (2015) about teacher education graduate tracer studies from 2010 to 2014 in one state university in Batangas, Philippines.

Even so, the graduate user satisfaction survey only uses descriptive statistical analysis, not using clustering. Likewise, the clustering research above is not related to the satisfaction of university graduates. By using clustering methods, specifically nonhierarchical cluster analysis or K-Means cluster analysis, it is expected to enrich the treasury of user satisfaction surveys and encourage in-depth research related to college graduates, not limited to tracer study.

\section{METHOD}

This study was conducted using secondary data from the user satisfaction survey results of graduates of the State Islamic Institute of Shaykh Abdurrahman Siddik Bangka Belitung in 2019. The data presented includes several factors that are indicators of graduate user satisfaction consisting of (1) implementation of Islamic values, (2 ) integrity, ethics, morals, (3) expertise based on knowledge (professionalism), (4) foreign language skills, (5) Information and Communication Technology skills, (6) communication, (7) teamwork, and (8) self-development (appendix BAN-PT Regulation No. 59 of 2018 concerning Guidelines for Preparation of Self Evaluation Reports, Guidelines for Preparation of Higher Education Performance Reports, and Assessment Matrix in Higher Education Accreditation Instruments). The number of samples analyzes in this study were 211 graduates from five study programs, namely Islamic Religious Education (PAI), Early Childhood Education (PIAUD), English Tadris (TBI), Islamic Guidance and Counseling (BKI), and Banking Sharia (PS). Data analysis using descriptive and multivariate statistics with non-hierarchical cluster analysis or K-Means cluster analysis methods. The selection of this analysis was based on the variables that will be grouped with known indicators on each variable.

\section{RESULT AND DISCUSSION}

The graduate user satisfaction survey data were then transformed (changed to a standard score) with the formula: $\mathrm{z}=(\mathrm{x}-$ $\mu) / \sigma)$. This process was assisted with SPSS/Statistical Package for Social Science software. The results of the transformation can be seen in the following table: 
Table 1. Descriptive Data

\begin{tabular}{|c|c|c|c|c|c|}
\hline Indicator & $\mathbf{N}$ & Minimum & Maxsium & Mean & $\begin{array}{c}\text { Std. } \\
\text { Deviation }\end{array}$ \\
\hline Implementation of Islamic values & 211 & .00 & 8.00 & 6.901 & 1.127 \\
\hline Integrity, ethics, morals & 211 & 14.00 & 28.00 & 23.701 & 3.330 \\
\hline $\begin{array}{l}\text { Expertise based on the field of } \\
\text { science (prodessionalism) }\end{array}$ & 211 & 7.00 & 16.00 & 12.630 & 1.939 \\
\hline Foreign languages skills & 211 & .00 & 8.00 & 4.602 & 1.336 \\
\hline ICT skills & 211 & 3.00 & 12.00 & 8.872 & 1.658 \\
\hline Communication & 211 & 8.00 & 16.00 & 12.991 & 1.831 \\
\hline Teamwork & 211 & 6.00 & 12.00 & 9.512 & 1.439 \\
\hline Self-development & 211 & 6.00 & 12.00 & 9.493 & 1.547 \\
\hline Valid N (listwise) & 211 & & & & \\
\hline
\end{tabular}

Furthermore, based on the results of data processing from respondents with the help of SPSS software, it was seen that all variables differed significantly because of the significant value $<0.05$. Also, the $F$ value indicates which indicators have high differences in each respondent. It appears that the highest $F$ value on the indicator of selfdevelopment, which is equal to 202,929 . The complete data processing results can be seen in Table 2 below.

Table 2. Anova Tes

\begin{tabular}{|c|c|c|c|c|c|c|}
\hline & \multicolumn{2}{|c|}{ Cluster } & \multicolumn{2}{|c|}{ Eroor } & \multirow[b]{2}{*}{$\mathrm{F}$} & \multirow[b]{2}{*}{ Sig } \\
\hline & Mean Squqre & Df & Mean Squqre & Df & & \\
\hline $\begin{array}{l}\text { Zscore: Implementation } \\
\text { of Islamic values }\end{array}$ & 35.075 & 2 & .672 & 208 & 52.167 & .000 \\
\hline $\begin{array}{l}\text { Zscore: Integrity, ethics, } \\
\text { morals }\end{array}$ & 64.157 & 2 & .393 & 208 & 163.363 & .000 \\
\hline $\begin{array}{l}\text { Zscore: Expertise based } \\
\text { on the fild of science } \\
\text { (professionalism) }\end{array}$ & 61.131 & 2 & .422 & 208 & 144.925 & .000 \\
\hline $\begin{array}{l}\text { Zscore Foreign Language } \\
\text { skills }\end{array}$ & 11.797 & 2 & .890 & 208 & 13.164 & .000 \\
\hline Zscore ICT Skills & 21.888 & 2 & .799 & 208 & 27.389 & .000 \\
\hline Zscore Communication & 66.771 & 2 & .368 & 208 & 181.646 & .000 \\
\hline Zscore Teamwork & 63.374 & 2 & .400 & 208 & 158.338 & .000 \\
\hline Zscore Self-development & 69.422 & 2 & .342 & 208 & 202.929 & .000 \\
\hline
\end{tabular}

After standardized data, cluster formation (3 clusters) was performed using the non-hierarchical cluster analysis or KMeans cluster analysis method. The formation of these three clusters was based on efforts to limit the number of groups and similarity of object characteristics (Pravitasari 2009) which was seen from their ability to be known, namely high ability, medium ability, and low ability. K-Means cluster analysis modeling was used with SPSS software. The complete clustering results can be seen in Table 3 below. 
Tabel 3. Cluster Formation Results

\begin{tabular}{lccc}
\hline \multicolumn{1}{c}{ Variable } & \multicolumn{3}{c}{ Cluster } \\
& $\mathbf{1}$ & $\mathbf{2}$ & $\mathbf{3}$ \\
\hline Zscore: Implementation of Islamic value & -.894 & .770 & -.246 \\
Zscore: Integrity, ethics, morals & -1.165 & 1.052 & -.350 \\
Zscore: Expertise based on the field of science & -1.357 & .961 & -.248 \\
(professionalism) & & & \\
Zscore: Foreign language skills & -.798 & .287 & .022 \\
Zscore: ICT Skills & -1.064 & .418 & .008 \\
Zscore: Communications & -1.185 & 1.074 & -.301 \\
Zscore: Teamwork & -1.274 & 1.01417 & -.301 \\
Zscore: Self development & -1.565 & .974 & -.205 \\
\hline
\end{tabular}

From the results of data processing with SPSS software, obtained the number of respondent members of each cluster. As presented in Table 4, the composition of the members of each cluster varies and forms a ranking. The cluster with the smallest number was cluster 1, which is 28 people or $13.27 \%$. While cluster 3 which totaled 114 people or $54.03 \%$ was the largest. While cluster 2, amounting to 69 people or $32.7 \%$ is in the middle.
Table 4. Number of Cases in each

\begin{tabular}{lrr} 
& \multicolumn{2}{c}{ Cluster } \\
\hline Cluster & 1 & 28.000 \\
\cline { 2 - 3 } & 2 & 69.000 \\
& 3 & 114.000 \\
Valid & & 211.000 \\
Missing & .000 \\
\hline
\end{tabular}

Furthermore, based on Table 1 and Table 3 , the average value of each cluster is calculated. The formula used is $\mathrm{x}=\mu+\mathrm{z} * \sigma$. The following table is the result of the calculation.

Table 5. Average Value of Each Cluster

\begin{tabular}{|c|c|c|c|c|c|c|c|c|c|c|c|}
\hline \multirow{2}{*}{ Variable } & \multicolumn{3}{|c|}{ Cluster } & \multirow[b]{2}{*}{$\mu$} & \multirow[b]{2}{*}{ 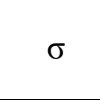 } & \multicolumn{3}{|c|}{ Cluster $\left(X=\mu+Z^{*} \sigma\right)$} & \multicolumn{3}{|c|}{ Category } \\
\hline & 1 & 2 & 3 & & & 1 & 2 & 3 & 1 & 2 & 3 \\
\hline $\begin{array}{l}\text { Zscore: } \\
\text { Implementation of } \\
\text { Islamic values }\end{array}$ & -0.894 & 0.770 & -0.246 & 6.901 & 1.127 & 5.893 & 7.768 & 6.623 & $\mathrm{R}$ & $\mathrm{T}$ & $S$ \\
\hline $\begin{array}{l}\text { Zscore: Integrity, } \\
\text { ethics, morals }\end{array}$ & -1.165 & 1.052 & -0.350 & 23.701 & 3.330 & 19.821 & 27.203 & 22.535 & $\mathrm{R}$ & $\mathrm{T}$ & $S$ \\
\hline $\begin{array}{l}\text { Zscore: Expertise } \\
\text { based on the field of } \\
\text { science } \\
\text { (professionalism) }\end{array}$ & -1.357 & 0.961 & -0.248 & 12.630 & 1.939 & 10.000 & 14.493 & 12.149 & $\mathrm{R}$ & $\mathrm{T}$ & $S$ \\
\hline $\begin{array}{l}\text { Zscore: Foreign } \\
\text { language skills }\end{array}$ & -0.798 & 0.287 & 0.022 & 4.602 & 1.336 & 3.536 & 4.986 & 4.632 & $\mathrm{R}$ & $\mathrm{T}$ & $S$ \\
\hline Zscore: ICT Skills & -1.064 & 0.418 & 0.008 & 8.872 & 1.658 & 7.107 & 9.565 & 8.886 & $\mathrm{R}$ & $\mathrm{T}$ & S \\
\hline $\begin{array}{l}\text { Zscore: } \\
\text { Communication }\end{array}$ & -1.185 & 1.074 & -0.359 & 12.991 & 1.831 & 10.821 & 14.956 & 12.333 & $\mathrm{R}$ & $\mathrm{T}$ & $S$ \\
\hline Zscore: Teamwork & -1.274 & 1.014 & -0.301 & 9.512 & 1.439 & 7.679 & 10.971 & 9.079 & $\mathrm{R}$ & $\mathrm{T}$ & $S$ \\
\hline $\begin{array}{ll}\begin{array}{l}\text { Zscore: } \\
\text { development }\end{array} & \text { Self- } \\
\end{array}$ & -1.565 & 0.974 & -0.205 & 9.493 & 1.547 & 7.071 & 11.000 & 9.175 & $\mathrm{R}$ & $\mathrm{T}$ & $S$ \\
\hline
\end{tabular}

Table 5 above shows the division of three clusters based on three characteristics. Cluster 2 is a cluster of graduates with high competency characteristics. Cluster 3 is a cluster of graduates with moderate competency characteristics. Whereas cluster 1 is a cluster of graduates with low competency 
characteristics. Based on Table 3 and Table 5 above, it appears that:

In cluster 1 (low), all indicators have the smallest average value and all of them are below the average population value $(\mu)$. The following is the average value of each indicator in cluster 1: (a) The application of Islamic values has a mean value of 5,893, below the population mean of 6,901 (difference: -1,008). (b) Integrity, ethics, and morals have an average value of 19,821, below the mean population value of 23,701 (difference: -3,880). (c) Expertise based on the field of science (professionalism) has an average value of 10,000 , below the population average value of 12,630 (difference: -2,630). (d) Foreign language ability has an average value of 3,536 , below the mean population value of 4,602 (difference: -1,066). (e) The ability to use ICT has a mean value of 7,107 , below the mean population value of 8,872 (difference: -1,765). (f) Communication skills have a mean value of 10,821 , below the mean population value of 12,991 (difference: 2.169). (g) Teamwork has a mean value of 7,679 , below the mean population value of 9,512 (difference: -1,833). (h) Selfdevelopment has a mean value of 7,071 , below the average population value of 9,493 (difference: -2,421).

In cluster 2 (high) all indicators have the highest mean values and all of them are above the population mean values $(\mu)$. The following is the average value of each indicator in cluster 1: a) The application of Islamic values has a mean value of 7,768 , above the population average of 6,901 (difference: 0.868). b) Integrity, ethics, and morals have an average value of 27,203, above the average population value of 23,701 (difference: 3,501). c) Expertise based on the field of science (professionalism) has an average value of 14,493 , above the average population value of 12,630 (difference: 1,862). d) foreign language skills have a mean value of 4,986 , above the mean population value of 4,602 (difference: 0.384). e) The ability to use ICT has an average value of 9,565 , above the mean population value of 8,872 (difference: 0.693). f) Communication skills have a mean value of 14,956 , above the mean population value of 12,991 (difference: 1,966). g) Teamwork has an average value of 10,971 , above the mean population value of 9,512 (difference: 1,459). h) Selfdevelopment has an average value of 11,000, above the average population value of 9,493 (difference: 1,507).

As for cluster 3 (moderate), of the eight indicators, two indicators have a mean value above the average population value $(\mu)$, namely foreign language skills and the ability to use ICT, while the other six indicators have a mean value below the mean value population. The following is the average value of each indicator in cluster 3: a) The application of Islamic values has a mean value of 6,623 , below the population mean of 6,901 (difference: -0,278). b) Integrity, ethics, and morals have an average value of 22,535 , below the average population value of 23,701 (difference: -1.166). c) Expertise based on the field of science (professionalism) has a mean value of 12,149 , below the average population value of 12,630 (difference: -0,481). d) The ability of foreign languages has a mean value of 4,632 , above the mean population value of 4,602 (difference: 0.030 ). e) The ability to use ICT has an average value of 8,886 , above the mean population value of 8,872 (difference: 0.014). f) Communication skills have a mean value of 12,333 , below the mean population value of 12,991 (difference: -0,657). g) Teamwork has an average value of 9,079, below the mean population value of 9,512 (difference: -0,433). h) Self-development has a mean value of 9,175 , below the mean population value of 9,493 (difference: $0,317)$.

The output results as in Table 5 above can illustrate the competency characteristics of graduates of five study programs at IAIN SAS Bangka Belitung based on the assessment of graduate users. In cluster 1, graduate users considered that graduates of IAIN SAS Bangka Belitung could apply low Islamic values, low ethical-moral integrity, low expertise based on the field of science (professionalism), low foreign language skills, ability to use ICT poor communication skills, low communication skills, low teamwork skills, and low personal 
development. In this cluster, there are 28 graduates or $13.27 \%$, who are rated by users as having low competence, and all indicators have a mean value below the population average $(\mu)$.

In cluster 2, users considered that graduates of IAIN SAS Bangka Belitung had high abilities. All indicators have a mean value above the population mean value $(\mu)$, both the application of Islamic values, integrity-ethics-morals, expertise based on the field of science (professionalism), foreign languages, the use of ICTs, teamwork, communication, and self-development. In this cluster, there were 69 graduates or $32.7 \%$.

In cluster 3 , the user considers that graduates of IAIN SAS Bangka Belitung can apply moderate Islamic values, moderate integrity-moral-ethics, expertise based on the current field of science (professionalism), moderate foreign language skills, ability to use ICTs that are moderate, moderate teamwork abilities, moderate communication skills, and moderate self-development. Based on the characteristics possessed, this cluster is called a graduate cluster which is considered to be a graduate user having moderate competence. In this cluster, there are 114 people or $54.03 \%$ with 2 indicators having a mean value above the average population value $(\mu)$, namely aspects of foreign language ability and aspects of the ability to use ICT.

From the description above, it can be seen that in general, users consider the majority of graduates of IAIN SAS Bangka Belitung to be in the moderate category $(54.03 \%)$, as indicated in cluster 3. If it refers to the views of Setyaningsih \& Abrori (2013), it can be interpreted that more than half of the graduate users considered that the quality of graduates of IAIN SAS Bangka Belitung was under their expectations and perceptions. Even so, there are still quite a lot of users who have negative perceptions and are not or are not satisfied with the quality of graduates (13.27\%).

As the tracer study conducted by various universities, the results of this survey (and previous surveys) provide a lot of information, both about the condition of graduates and the process of education and learning at IAIN SAS Bangka Belitung. This information and feedback can be taken into consideration in formulating policies to improve the quality of education and learning processes and outcomes (Akbar \& Mukhtar, 2019; Rahim, 2017; Sangadji, 2015). One effort that can be done so that users have a good perception of the quality of graduates is the implementation of human resource development programs to shape the mentality and competence of qualified and competitive students especially those related to the following eight indicators: the ability to apply Islamic values, integrity-ethics-morals, expertise based on the field of science (professionalism), foreign language skills, ability to use ICT, communication skills, teamwork abilities, and self-development.

Furthermore, it is also understood that quality issues are inseparable from internal and external factors. Therefore, the involvement of all parties, including graduate users, is actively and continuously becoming an important element so that universities, in this case, IAIN SAS Bangka Belitung, can become quality human resource providers and are ready to be used by users (Mutaqin in Santyadiputra \& Agustini 2016; Setyaningsih $\&$ Abrori 2013). This involvement of users as external parties is important so that difficulties, as mentioned by Sarino et al (2012), can be overcome because there is direct monitoring of the needs and desires of users.

However, the information obtained is not optimal due to the low response rates of alumni and users in tracer studies, which are only 211. This condition is an important note for IAIN SAS Bangka Belitung to develop a better tracer study system by considering aspects of effectiveness, efficiency, and user satisfaction and information technologybased. This system, known as e-tracer, was developed in an integrated manner with the university website. This e-tracer system is proven to be able to overcome various problems that are often encountered in tracer studies manually due to distance and busyness of alumni or users (Akbar \& Mukhtar, 2019; 
Khasanah, 2019; Primasari, 2018; Suryani et al., 2017). That way, the results obtained from the tracer study can be under the expected goals to improve the quality of graduates and campus development.

\section{CONCLUSION AND RECOMMENDATION}

This study tries to apply the techniques or methods of non-hierarchical cluster analysis or K-Means cluster analysis to identify and classify the competency characteristics of IAIN SAS Bangka Belitung graduates. Based on the results of data analysis and discussion, it can be concluded that there are differences in the characteristics of graduate competencies and are classified into three clusters, namely high, medium, and low. Low cluster (cluster 1) has the characteristics of graduates with low competence, which is equal to $13.27 \%$. Medium cluster (cluster 3) has the characteristics of graduates with moderate competence, which is equal to $54.03 \%$. While the high cluster (cluster 2) has the character of graduates with high competence, which is $32.7 \%$. Differences in the characteristics of graduate competencies are influenced by aspects of the ability to apply Islamic values, integrity-ethics-morals, expertise based on the field of science (professionalism), foreign language skills, ICT skills, teamwork abilities, communication skills, and selfdevelopment.

Although still limited and simple, the results of this survey are expected to be followed up by the IAIN SAS Bangka Belitung by making policies and developing strategic, systematic, comprehensive, and continuous steps in the framework of increasing graduates' competency and competitiveness according to the profile and needs of the world of work or the user. Some important things that IAIN SAS Bangka Belitung must do to maximize the results of tracer studies are: (1) developing an e-tracer system based on information technology and integrated with the SAS Bangka Belitung IAIN website so that tracer studies can cover a greater number of graduates and regions more broadly; (2) involving stakeholders, both internal and external IAIN SAS Bangka Belitung, more actively, intensively, and extensively. By doing so, the information obtained from tracer studies can be maximized and provide feedback for efforts to improve the competence and competitiveness of graduates under the profile and in harmony with the needs of users and the development of the world of work.

\section{REFERENCES}

Adeniran, P. (2011). User satisfaction with academic libraries services: Academic staff and students perspectives. International Journal of Library and Information Science, 3(10), 209-216. https://doi.org/10.5897/IJLIS.900011 4

Aquino, A. B., Punongbayan, E. J., Macalaguim, L. P., Bauyon, S. M., Rodriguez Jr, R. A., \& Quizon, G. R. (2015). Teacher education graduate tracer study from 2010 to 2014 in one state university in Batangas, Philippines. Asia Pacific Journal of Multidisciplinary Research, 3(5), 4550.

Aranda, J., \& Natasya, W. A. G. (2016). Penerapan Metode K-Means Cluster Analysis Pada Sistem Pendukung Keputusan Pemilihan Konsentrasi Untuk Mahasiswa International Class STMIK AMIKOM Yogyakarta. Semnasteknomedia Online, 4(1), 4-2.

Arifin, M., \& Muzid, S. (2018). Analisa Tracer Studi Pada Universitas XYZ. Jurnal Disprotek, 9(2), 69-73. https://doi.org/10.34001/jdpt.v9i2.799

Bertaccini, B., Bacci, S., \& Petrucci, A. (2021). A graduates' satisfaction index for the evaluation of the university overall quality. SocioEconomic Planning Sciences, 73, 100875.

https://doi.org/10.1016/j.seps.2020.10 0875

Calpa, M. J. B., Esquierdo, I. E., \& Unay, O. D. (2021). Tracer Study of Bs in 
Mathematics Graduates (2001-2015) of the College of Science, University of Eastern Philippines. Asian Research Journal of Mathematics, 38-44.

https://doi.org/10.9734/arjom/2021/v1 7i130263

Chen, X., \& Duan, S. (2019). Research on clustering analysis of Internet public opinion. Cluster Computing, 22(3), 5997-6007.

Christensen, C. M., Horn, M. B., \& Johnson, C. W. (2011). Disrupting class: How disruptive innovation will change the way the world learns (Vol. 1). McGraw-Hill New York.

Ciriaci, D. (2014). Does university quality influence the interregional mobility of students and graduates? The case of Italy. Regional Studies, 48(10), 15921608.

https://doi.org/10.1080/00343404.201 3.821569

Dorji, N., \& Singh, K. B. (2020). Tracer study: An analysis of 2018 graduates of gedu college of business studies, Bhutan. International Journal of Advanced Science and Technology, 29(6), 1680-1686.

Ediyanto, M. N. M., \& Satyahadewi, N. (2013). Pengklasifikasian Karakteristik Dengan Metode KMeans Cluster Analysis. BIMASTER, 2(02)

http://dx.doi.org/10.26418/bbimst.v2i 02.3033

Gunarto, M., \& Septayuda, I. (2016). Analisis Ekuitas Merek dalam Persaingan Perguruan Tinggi Swasta di Kota Palembang. Jurnal Ilmiah MBiA Ilmu Ekonomi Fakultas Ekonomi Universitas Bina Darma, 15(2).

Hafiz, A. (2020). Tracer Study Alumni Prodi Pendidikan Islam Anak Usia Dini STAIN Gajah Putih Takengon. Jurnal As-Salam, 4(1), 1-12. https://doi.org/10.37249/assalam.v4i1. 150

Hatidja, D., Momuat, L. I., \& Mongi, C. E. (2018). Pengelompokkan Mata Kuliah Di Program Studi Fisika FMIPA UNSRAT Berdasarkan Proses Pembelajaran Menggunakan Analisis Cluster. Jurnal Ilmiah Sains, 18(2), 107-112. https://doi.org/10.35799/jis.18.2.2018. 21556

Hazaymeh, E. N., \& Dela Peña, M. K. (2017). A tracer study of La Salle University College of Engineering graduates. Retrieved August, 18(1), 52-68.

Heriyadi, B. (2021). Tracer Study Analysis for the Reconstruction of the Mining Vocational Curriculum in the Era of Industrial Revolution 4.0. Turkish Journal of Computer and Mathematics Education (TURCOMAT), 12(3), 3013-3019. doi:10.17762/turcomat.V12I3.1335

Hilliard, A. T. (2015). Global Blended Learning Practices for Teaching and Learning, Leadership and Professional Development. Journal of International Education Research, 11(3), 179-188.

Imron, A., \& Farda, U. J. (2019). Tracer Study: Keterserapan Dan Kepuasan Pengguna Alumni PGMI UNWAHAS Lulusan Tahun 2015, 2016 DAN 2017. MAGISTRA: Media Pengembangan Ilmu Pendidikan Dasar Dan Keislaman, 10(1).

Irmeilyana, I., Sania, R., Desiani, A., \& Tanuji, H. (2017). Peng-cluster-an Mahasiswa Berdasarkan IPK dan IP Kelompok Mata Kuliah dan Kelompok Bidang Minat. Annual Research Seminar (ARS), 3(1), 149156.

Izogo, E. E., \& Ogba, I.-E. (2015). Service quality, customer satisfaction and loyalty in automobile repair services sector. International Journal of Quality \& Reliability Management. 
https://doi.org/10.1108/IJQRM-052013-0075

Jain, R., Sinha, G., \& Sahney, S. (2011). Conceptualizing service quality in higher education. Asian Journal on Quality.

https://doi.org/10.1108/159826811111 87128

Johnson, R. A., \& Wichern, D. W. (2014). Applied multivariate statistical analysis (Vol. 6). Pearson London, UK:

Jurnal, J. (2019). Evaluasi e-Tracer Study menggunakan HOT (HumanOrganization-Technology) Fit Model. Jurnal JTIK (Jurnal Teknologi Informasi Dan Komunikasi), 3, 2. https://doi.org/10.35870/jti k.v3i2.86

Kalaw, M. T. B. (2019). Tracer Study of Bachelor of Science in Mathematics. International Journal of Evaluation and Research in Education, 8(3), 537548. doi: 10.11591/ijere.v8i3.17343

Kartika, A. D., Samsul, S. I., Pujosusanto, A., \& Ridwan, A. (2019). The Correlation between Tracer Study and Curriculum Relevance. Social Sciences, Humanities and Education Conference (SoSHEC 2019), 98-101.

Khasanah, U. (2019). Tracer study as an effort to improve higher islamic education quality and relevance. ATTARBIYAH: Journal of Islamic Culture and Education, 4(2), 121143.

Lucitasari, D. R., \& Khannan, M. S. A. (2019). Designing Mobile Alumni Tracer Study System Using Waterfall Method: An Android Based. International Journal of Computer Networks and Communications Security, 7(9), 196-202.

Nasari, F., \& Darma, S. (2013). Penerapan kmeans clustering pada data penerimaan mahasiswa baru (studi kasus: Universitas potensi utama). Semnasteknomedia Online, 3(1), 2-1.

Odame, L., Osei-Hwedie, B., Nketsia, W., Opoku, M. P., \& Nanor Arthur, B. (2021). University preparation and the work capabilities of visually impaired graduates in Ghana: A tracer study. International Journal of Inclusive Education, 25(11), 1287-1304. https://doi.org/10.1080/13603116.201 9.1609102

Övgü Çakmak-Otluoğlu, K. (2018). A cluster analysis of protean and boundaryless career orientations: Relationships with career competencies. Australian Journal of Career Development, 27(3), 127-136. https://doi.org/10.1177/103841621774 3024

Poerwanto, B., \& Fa'rifah, R. Y. (2016). Analisis cluster k-means dalam pengelompokan kemampuan mahasiswa. Indonesian Journal of Fundamental Sciences, 2(2), 92-96.

Pradela, A. (2015). Quality of graduates' preparation for labour Market-A SERVQUAL analysis. ProcediaSocial and Behavioral Sciences, 174, 1671-1677.

https://doi.org/10.1016/j.sbspro.2015. 01.820

Pravitasari, A. A. (2009). Penentuan Banyak Kelompok dalam Fuzzy C-Means Cluster Berdasarkan Proporsi Eigen Value Dari Matriks Similarity dan Indeks XB (Xie dan Beni). Seminar Nasional Matematika Dan Pendidikan Matematika, 623.

Primasari, C. H. (2018). Pengembangan Sistem Informasi Portal Alumni dengan Tracer Study dan Survey Pengguna Alumni Universitas Atma Jaya Yogyakarta. https://doi.org/10.24002/jbi.v9i1.1498

Pyrhönen, V.-P., Niiranen, S., \& Pajarre, E. (2020). Newly graduate engineers' development of expertise and personal 
competencies.

doi:10.22503/inftars.XX.2020.2.5

Rahim, M., \& Puluhulawa, M. (2018). Tracer Study Lulusan Program Studi Bimbingan dan Konseling Universitas Negeri Gorontalo. JP (Jurnal Pendidikan): Teori Dan Praktik, 2(2), 121-127. https://doi.org/10.26740/jp.v2n2.p121127

Rantesalu, M. B. (2019). Withdrawn: Analysis Of User Satisfaction Graduate Program Study For Christian Education Religion, State Christian Religion, Kupang In 2019. Withdrawn: Analysis of User Satisfaction Graduate Program Study For Christian Education Religion, State Christian Religion, Kupang In 2019. doi : 10.31220/osf.io/qynfr

Rogan, M., \& Reynolds, J. (2016). Schooling inequality, higher education and the labour market: Evidence from a graduate tracer study in the Eastern Cape, South Africa. Development Southern Africa, 33(3), 343-360. https://doi.org/10.1080/0376835X.201 6.1153454

Safi'i, I., \& Priyantoro, P. (2019). Tracer Study as an Effort to Improve Alumni Careers in Kadiri University Job Placement Service. KONSELI: Jurnal Bimbingan Dan Konseling (EJournal), 6(2), 157-166. https://doi.org/10.24042/kons.v6i2.51 95

Santyadiputra, G. S., \& Agustini, K. (2016). Survey Kualitas Lulusan Jurusan Pendidikan Teknik Informatika. Jurnal Pendidikan Teknologi Dan Kejuruan, 13(1), 13-22. http://dx.doi.org/10.23887/jptkundiksh a.v13i1.6843

Schomburg, H. (2014). Key Methodological Issues of Tracer Studies-Challenges for a Guide on Tracer Studies. Proceedings from Presentation at the Validation Seminar on
Methodological Guides for Skills Anticipation and Matching. CedefopILO-ETF Expert Seminar (Prague, 67 March 2014). National Training Fund

Setyaningsih, I., \& Abrori, M. (2013). Analisis Kualitas Lulusan Berdasarkan Tingkat Kepuasan Pengguna Lulusan. Jurnal Ilmiah Teknik Industri, 12(1), 73-82.

Shah, M., Grebennikov, L., \& Nair, C. S. (2015). A decade of study on employer feedback on the quality of university graduates. Quality Assurance in Education. https://doi.org/10.1108/QAE-04-20140018

Soegoto, H. S., Wahdiniwaty, R., Warlina, L., \& Heryandi, A. (2018). E-tracer study implementation of Indonesia Computer University alumni. Journal of Educational Research and Reviews, 6(2), 38-46.

Summers, S. (2016). Building expertise: The toolkit in UCLA's graduate writing center. The Writing Center Journal, 117-145.

Teeroovengadum, V., Kamalanabhan, T. J., \& Seebaluck, A. K. (2016). Measuring service quality in higher education: Development of a hierarchical model (HESQUAL). Quality Assurance in Education.

https://doi.org/10.1108/QAE-06-20140028

West, D. C., Ford, J. B., \& Ibrahim, E. (2015). Strategic marketing: Creating competitive advantage. Oxford University Press, USA.

Xu, F., \& Du, J. T. (2019). Examining differences and similarities between graduate and undergraduate students' user satisfaction with digital libraries. The Journal of Academic Librarianship, 45(6), 102072. https://doi.org/10.5897/IJLIS.9000114 